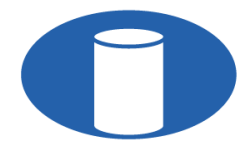

IBRACON Structures and Materials Journal

Revista IBRACON de Estruturas e Materiais

IBRACON

ISSN 1983-4195

ismj.org

ORIGINAL ARTICLE

\title{
Study of red ceramic residues as pigments in matrices based on white Portland cement
}

\section{Estudo de resíduos de cerâmica vermelha como pigmentos em matrizes de cimento Portland branco}

\author{
Letícia Andreolli Dias ${ }^{\mathrm{a}}$ \\ Fernanda Boll Birck ${ }^{\mathrm{a}}$ \\ Lucas Kaefer ${ }^{\mathrm{a}}$ (1) \\ Daiana Cristina Metz Arnold ${ }^{a}$ (D) \\ Alexandre Silva de Vargas ${ }^{b}$ (D)
}

${ }^{a}$ Universidade Feevale, Engenharia Civil, Novo Hamburgo, RS, Brasil

${ }^{b}$ Universidade Federal de Santa Maria - UFSM, Engenharia Civil, Santa Maria, RS, Brasil

Received 06 June 2020

Accepted 11 March 2021

\begin{abstract}
The present study evaluated the use of red ceramic residues (RCR) as pigments in matrices based on White Portland cement. Five mortars were prepared for the present study: control mortar (M0), at 1:2,3 ratio (cement: sand) and water/cement ratio of 0.60 , other four mortars were prepared containing RCR in $10 \%$ (M10), 20\% (M20), 50\% (M50), 100\% (M100) of volume in replace to the sand. Colorimetric tests indicated a significant increase in the coloring, due to the increase of the RCR used. Tests of resistance to compression strength indicated a significant increase in the results as there was an increase in the substitution content of the sand by RCR. In the flexural tensile strength was no significant influence for contents of up to $50 \%$. Therefore, the RCR showed potential as a pigmentation product and can contribute to the increase in compressive strength in Portland cement-based matrices.
\end{abstract}

Keywords: sand, pigments for mortar, red ceramic residues.

Resumo: O presente estudo avaliou a utilização de resíduos de cerâmica vermelha (RCR) como pigmentos em matrizes à base de cimento Portland Branco. Para o presente estudo foram preparadas cinco argamassas: argamassa de controle (M0), com traço, em massa, de 1:2,3 (cimento: areia) e relação água/cimento de 0,60; outras quatro argamassas foram preparadas contendo RCR, em substituição ao volume da areia, em teores de $10 \%$ (M10), 20\% (M20), 50\% (M50) e 100\% (M100). Os testes colorimétricos indicaram um aumento significativo na coloração, devido ao aumento do RCR utilizado. Ensaios de resistência à compressão indicaram aumento significativo nos resultados, com o aumento da substituição da areia pelo RCV. Na resistência à tração na flexão não houve influência significativa para teores de até $50 \%$ do RCR. Portanto, o RCR apresentou potencial como produto de pigmentação e pode contribuir para o aumento da resistência à compressão em matrizes à base de cimento Portland.

Palavras-chave: areia natural, pigmento para argamassa, resíduo de cerâmica vermelha.

How to cite: L. A. Dias, F. B. Birck, L. Kaefer, D. C. M. Arnold, and A. S. Vargas, "Study of red ceramic residues as pigments in matrices based on white Portland cement," Rev. IBRACON Estrut. Mater., vol. 14, no. 6, e14608, 2021, https://doi.org/10.1590/S1983-41952021000600008

\section{INTRODUCTION}

Sustainability is a major subject in construction industry nowadays, since a large fraction of solid residues is generated in constructions, resulting in high levels of environmental, social and economic impacts. The red ceramic

Corresponding author: Letícia Andreolli Dias. E-mail: leticia.dias.nh@hotmail.com

Financial support: None.

Conflict of interest: Nothing to declare. 
industry generates a representative amount of residues (RCR) because, due to requirements of quality, many products are discarded for presenting defects of production or for inadequate transportation [1].

By incorporating RCR in mortars and concretes, it is possible to partially replace the constituents of the mixtures, thus reducing the consumption of natural aggregates or binders. In the case of aggregates (sand), its excessive extraction can lead to disastrous environmental consequences, reason why, the incorporation of residues for its replacement can offer advantages in environmental, economic, and technical aspects.

Considering the above, the potential of the red ceramic residues (RCR) generated, due to their colorimetric characteristics and due to the inert materials they are made of, make them an attractive alternative for the incorporation in mortars and concretes for pigmentation purposes, reducing the inadequate deposition of the waste generated [2].

Buildings with colored mortars are an attractive alternative compared to traditional mortars that exhibit poor aesthetic properties, from the architectural point of view [3]. Pigmented constructions become popular among engineers and architects, in the application of facades, coatings and other decorative monuments. A very important aspect is to obtain permanent colors without producing adverse effects on mortars and the environment [4].

In this sense, the pigmentation of mortars is widely used in developed countries to replace the painting, considering that low price is an important characteristic to the advantage of decorative mortar, the use of residues can help in the process of diversifying the production, reducing final costs and allowing new possibilities for the reuse of this waste in order to minimize the environmental impacts of the ceramic industry [5].

Diamanti et al. [6] and Lemaire et al. [7] affirm that from the moment in which mortars and concrete are used as decorative material, the coloring becomes essential for the building, and not only its structural function. However, it is becoming increasingly important that mortars and concretes become more economical, durable and sustainable [1].

The organic and inorganic pigments used in mortars and concretes show very fine grains, as well as the RCR, causing greater absorption of water in the mixture and consequent decrease in the workability, when carrying out the tests of consistency [3]. López et al. [8] complements that since the pigment has particles of similar or smaller sizes of the cement particles, it is necessary to evaluate the increase in the water demand, emphasizing that a study of the mixture can improve the performance of it, considering the effects of the pigments on material cohesion and the adoption of plasticizing additives.

Concrete and mortar structures must have good resistance, since they must maintain their integrity for a long time, by analyzing the tensile resistance in the bending, Lee et al. [9] expose the importance of water absorption, because according to their study, the greater the water absorption was, the lower the tensile resistance was in the samples. According to Sales and Alferes [10], the characteristics of the materials incorporated to the mixture also have great influence in the resistance of the concrete, being verified that by the incorporation of the ceramic powder into concretes, the chemical and microstructural compositions of that residue reduced the tensile resistance in the bending.

Corinaldesi et al. [11] verified the decrease in compressive resistance of concretes and mortars that commercial pigments were added, when compared to the resistance of the materials without the pigment. On the other hand, Matias et al. [2] found that, unlike the commercial pigments, the RCR presented pozzolanic properties and filler effect, which contributes to increasing the mechanical strength by incorporating the residues in matrices based by Portland cement, due to the increased voids filled by having smaller grains (fillers) and pozzolanic reactions with the cement hydration products (Portlandite - $\mathrm{Ca}(\mathrm{OH}) 2 €)$. Thus, it is possible to observe that the RCR has potential to pigment cement matrices without damaging the mechanical properties of the composite.

Colorimetry is a good tool to rapidly evaluate the pigment anchoring on the hardened mortar a few weeks after demolding [12]. Li et al. [5] show that the chemical constituents of the residues used as pigments in mortars and concretes define their coloration, such as, for example, wastes with higher $\mathrm{Fe} 3+$ and $\mathrm{Pb} 3+$ ions, have a red coloring.

Considering the above, this article aims to analyze the influence of the replacement of natural quartz sand by RCR in the production of pigments for mortars, considering the physical properties of the residue, the mechanical performance of each mortar in the hardened state and the colorimetry test of the samples.

\section{MATERIALS AND EXPERIMENTAL PROGRAM}

\subsection{Materials}

The cement used for the preparation of the mortars was Structural White Portland cement (WPC - 40). The physical characteristics and chemical composition of cement are presented in Tables 1 and 2. 
Table 1. Physical characteristics of White Portland Cement.

\begin{tabular}{ccc}
\hline & White Portland Cement & Sand \\
\hline Specific mass & $2,97 \mathrm{~g} / \mathrm{cm}^{3}$ & - \\
\hline Fineness- residue on the sieve of $75 \mu \mathrm{m}$ & $0,3 \%$ & - \\
\hline Fineness- residue on the sieve of $45 \mu \mathrm{m}$ & $1 \%$ & - \\
\hline Unit mass & - & $1,615 \mathrm{~g} / \mathrm{cm}^{3}$ \\
\hline Finesse module & - & 2,19 \\
\hline Maximum grain size $(\mathrm{mm})$ & - & $2,4 \mathrm{~mm}$ \\
\hline
\end{tabular}

Table 2 shows the chemical composition of the cement used in the study, according to the tests performed by the manufacturer.

Table 2. Chemical characteristics of White Portland Cement.

\begin{tabular}{cc}
\hline Assay & \% of mass \\
\hline $\mathrm{SiO}_{2}$ & 20,86 \\
\hline $\mathrm{Al}_{2} \mathrm{O}_{3}$ & 4,16 \\
\hline $\mathrm{Fe}_{2} \mathrm{O}_{3}$ & 0,24 \\
\hline $\mathrm{CaO}$ & 63,3 \\
\hline $\mathrm{MgO}$ & 1,17 \\
\hline $\mathrm{SO}_{3}$ & 2,89 \\
\hline $\mathrm{Na}_{2} \mathrm{O}$ & 0,10 \\
\hline $\mathrm{K}_{2} \mathrm{O}$ & 0,43 \\
\hline $\mathrm{TiO}_{2}$ & 0,21 \\
\hline $\mathrm{SrO}_{4}$ & 0,04 \\
\hline $\mathrm{P}_{4} \mathrm{O}_{10}$ & 0,04 \\
\hline $\mathrm{MnO}_{2}$ & 0,02 \\
\hline $\mathrm{CaO}^{2}$ & 1,79 \\
\hline Insoluble residue & 0,57 \\
\hline $\mathrm{CO}_{2}$ & 3,99 \\
\hline $\mathrm{Alkaline}$ in $\mathrm{Na}_{2} \mathrm{O}$ & 0,38 \\
\hline
\end{tabular}

As fine aggregate, it was used river quartz sand. Data on sand characterization are presented in Table 1.

It was used red ceramic residue derived from broken or defective bricks from an industry located in the Valley of the Sinos - Brazil. The firing temperature of the bricks is controlled at $900{ }^{\circ} \mathrm{C}$. For the correct use of the residue, it underwent a beneficiation process, in which it was ground in a TS 2X20 / 600 Crusher, and milled in CT-241 Ball Mill for 12 minutes. The value of the specific mass and unit mass of the residue used was $2,57 \mathrm{~g} / \mathrm{cm}^{3} \mathrm{and} 0,84 \mathrm{~g} / \mathrm{cm}^{3}$, respectively. Figure 1 shows the granulometric curve of the RCR, determined by laser granulometry. The mean RCR diameter was $8 \mu \mathrm{m}$.

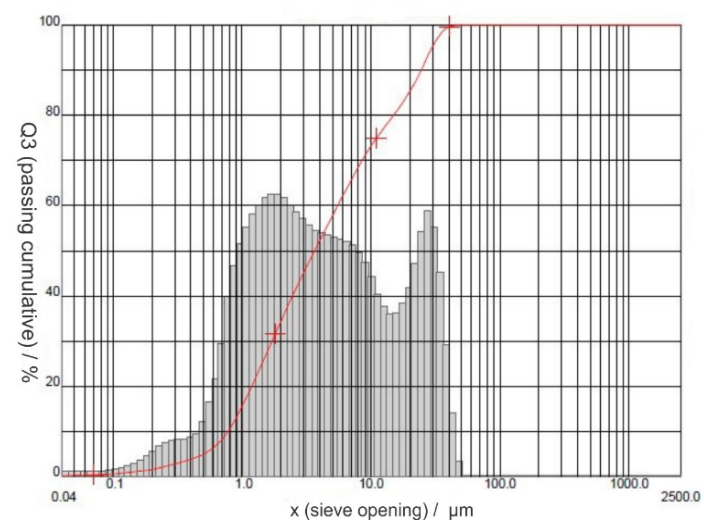

Figure 1. Laser granulometry ceramic process. 
Figures 2 and 3 show micrographs of the RCR obtained with the help of the scanning electron microscope (SEM). It is observed that the majority of the RCR particles are irregularly shaped and have a rough surface, which increases the exposed area of the grain.

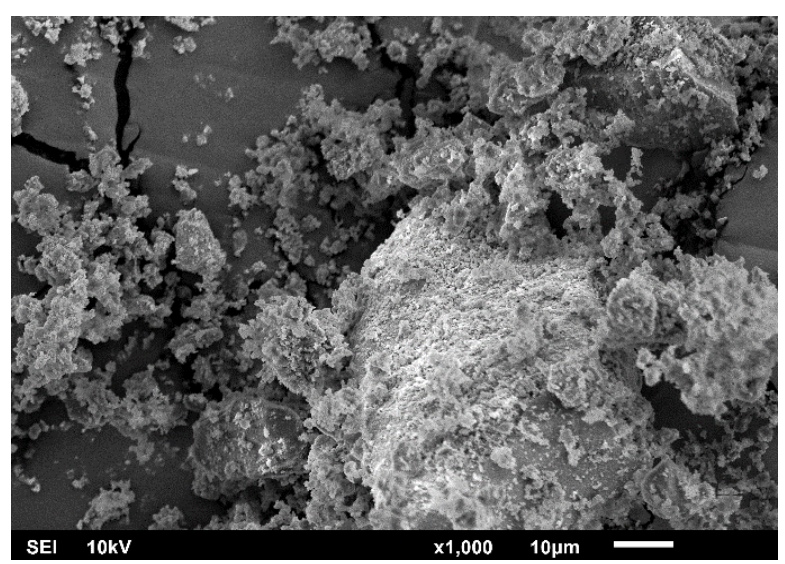

Figure 2. SEM Red ceramic - increase of $1.000 x$.

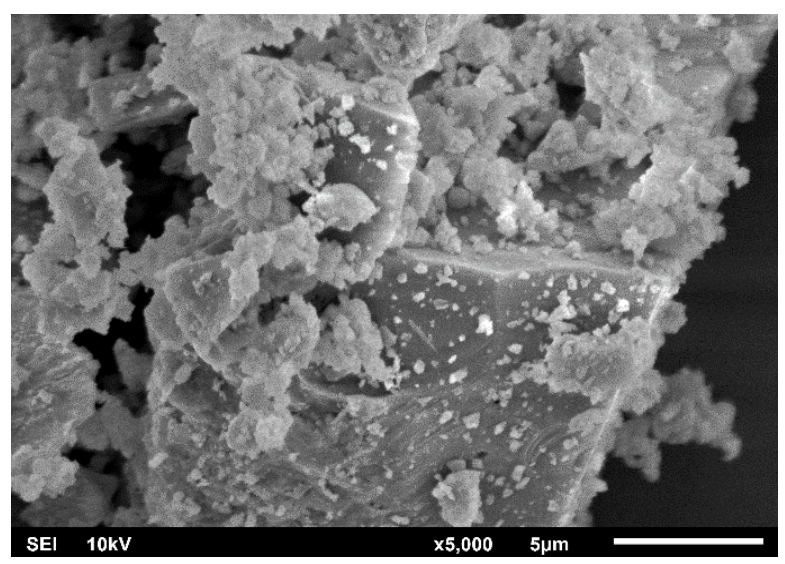

Figure 3. SEM Red ceramic - increase of 5.000x.

\subsection{Method}

Five mortars were prepared for the present study: control mortar (M0), at 1:2,3 ratio (cement: sand) and water/cement ratio of 0.60 ; other four mortars were prepared containing RCR in 10\% (M10), 20\% (M20), 50\% (M50), $100 \%$ (M100) of volume in replace to the natural sand, as shown in Table 3.

Table 3. Studied proportions.

\begin{tabular}{ccccccc}
\hline Matrix & Cement $(\mathbf{k g})$ & Sand (kg) & $\begin{array}{c}\text { Residue of } \\
\text { RCR (kg) }\end{array}$ & Water (kg) & $\begin{array}{c}\text { Additive } \\
\text { content }(\%)\end{array}$ & $\begin{array}{c}\text { Flow table } \\
(\mathbf{m m})\end{array}$ \\
\hline M0 & 0,850 & 1,955 & 0 & 0,51 & 0 & 292 \\
\hline M10 & 0,850 & 1,7595 & 0,1017 & 0,51 & 0 & 281 \\
\hline M20 & 0,850 & 1,564 & 0,2034 & 0,51 & 0 & 297 \\
\hline M50 & 0,850 & 0,9775 & 0,7206 & 0,51 & 3,85 & 289 \\
\hline M100 & 0,850 & 0 & 1,0168 & 0,51 & 0 \\
\hline
\end{tabular}


Since the specific masses of the sand and the RCR are different, the following equation was adopted to determine the masses of RCR and sand to be used for volume replacement of the contents presented previously.

$M a=\frac{M b}{Y b} \times Y a$

Where is mass of material (Ma), mass of material to be replaced (Mb), unit mass of material (Ya) and unit mass of material to be replaced $(\mathrm{Yb})$.

The preparation of the mortars was performed in a vertical axis mixer, for 90 seconds, at slow speed, according to the terms of the norm NBR 13276 [13]. Table 3 shows the traits and Consistency Index for each sample studied. In this work, it was adopted the consistency index of the mortars, measured at the flow table, of $280 \mathrm{~mm} \pm 20 \mathrm{~mm}$. According to Table 3, only for the sample M100 it was necessary to use a plasticizer additive in order to achieve that consistency index.

For the colorimetric assays, four prismatic samples $(4 \times 4 \times 8 \mathrm{~cm})$ were prepared for each mixture studied. In the compression strength and tensile strength tests, three prismatic samples $(4 \times 4 \times 16 \mathrm{~cm})$ were prepared for each mixture studied. After 48 hours the samples were removed from the prismatic molds, remaining at a controlled temperature of $23 \pm 2{ }^{\circ} \mathrm{C}$

\subsection{Colorimetric Analysis}

For the colorimetric analysis of the samples M0, M10, M20, M50 and M100, were used metal molds with the dimensions of $4 \times 4 \times 8 \mathrm{~cm}$. These samples were submitted to two different environments, during 28 days, described as follows:

- Environment exposed to atmospheric conditions: In this environment, two samples of each residue level remained outside the laboratory, exposed to the weather, in order to evaluate the effect of this environment on the coloration. In the 28-day period, temperatures ranged between $11.4^{\circ} \mathrm{C}$ and $38.1{ }^{\circ} \mathrm{C}$, the relative air humidity varied between $20 \%$ and $95 \%$, with rainfall occurring in 11 of the 28 days evaluated [14];

- Controlled environment: the two samples of each residue content remained in a environment of laboratory with a temperature of $23 \pm 2{ }^{\circ} \mathrm{C}$.

At the ages of 14 and 28 days, chromatic measurements were performed with the help of the Konica Minolta spectrophotometer, model CM-2600D.

The analyses were made using the CIElab method, in which it is used a mathematical treatment for the relative intensities of red, yellow, green, and blue radiation, seeking the uniformity of color spacing in the colorimetric space. Given its three-dimensional character, the color can be represented graphically by a system of perpendicular coordinates: $\mathrm{L}^{*}, \mathrm{a} *, \mathrm{~b} *$; the $\mathrm{L}^{*}$ being associated with the luminosity of the sample that varies from black to white. The coordinate $\mathrm{a} *$ when positive, means red tones and when negative, green tones, and $\mathrm{b} *$ that oscillates between yellow and blue tones when positive and negative, respectively [15].

Horgnies et al. [12] report that this method is effective for the fast evaluation of pigmentation in different areas of a sample, due to its three-dimensionality, and also presents precision when used with comparison effect of pigmentation, as will be carried out in the research.

Thus, the analyses were performed using the parameters $\mathrm{L} * \mathrm{a},{ }^{*} \mathrm{~b} *$. The transfer of the data collected for the On Color software enabled the configuration of the readings and the automatic calculation of the parameters $\mathrm{L}^{*}, \mathrm{a} *, \mathrm{~b} *$. However, since the color change is not originated only by the parameter $\mathrm{L}^{*}$ or shades, the color variation $(\Delta \mathrm{E})$ and the variation in the $\mathrm{L}^{*}$ axis were used as a criterion of comparison, since these are the parameters most noticeable to the observer.

\subsection{Tensile Strength}

For Tensile Strength analysis, 3 prismatic specimens with dimensions of $4 \times 4 \times 16 \mathrm{~cm}$ were molded for each RCR level, according to the requirements of NBR 13279 [16]. The specimens were demolded after 48 hours of molding, in a way that the rupture occurred at 28 days of cure. 


\subsection{Compressive Strength}

The compressive strength test used the ruptured half of the test specimens of the testing of Tensile Strength at 28 days of cure, according to NBR 13279 [16].

\section{RESULTS AND DISCUSSIONS}

Figures 4 and 5 show the samples in a laboratory environment and those exposed to the atmospheric conditions, at age of 28 days, in which it is possible to visualize the increase of the coloration with the addition of the replacement of the sand by the RCR.

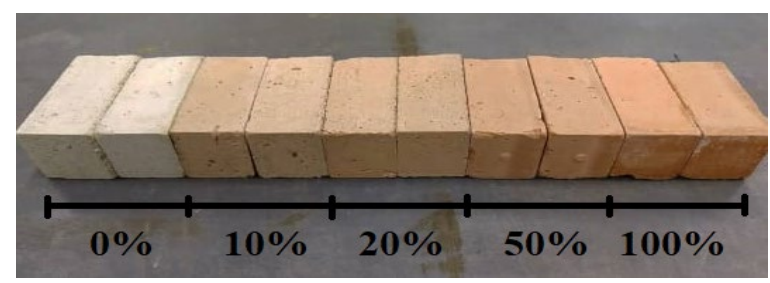

Figure 4. Samples of mortars in laboratory environment, aged 28 days.

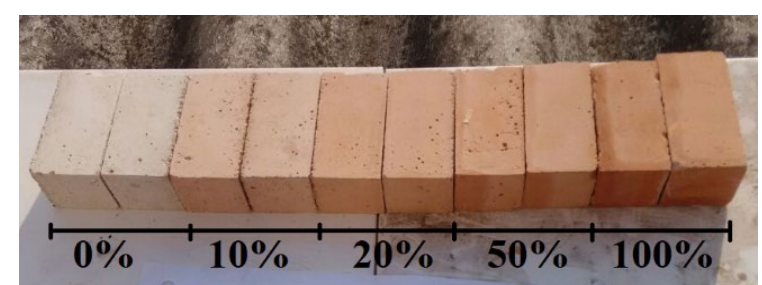

Figure 5. Samples of mortars exposed to atmospheric conditions, aged 28 days.

\subsection{Colorimetric Analysis}

The determination of the color change is specified for a total variation, not being possible to know if the differences are due to luminosity $\left(\mathrm{L}^{*}\right)$ or hue. Therefore, the color variation $\Delta \mathrm{E}$ and the variation in the $\mathrm{L} *$ axis were used as a comparison criterion, since these are the parameters with the most visually perceptible differences.

\subsubsection{Parameter $L^{*}$}

Figures 6,7 and 8 show the values of the parameter $\mathrm{L} *$ compared to the effect of red ceramic residue content and curing environment. In order to understand the analysis of the parameter $\mathrm{L} *$, it can be said in a more simplified way that the smaller the value of this parameter "the darker the color".

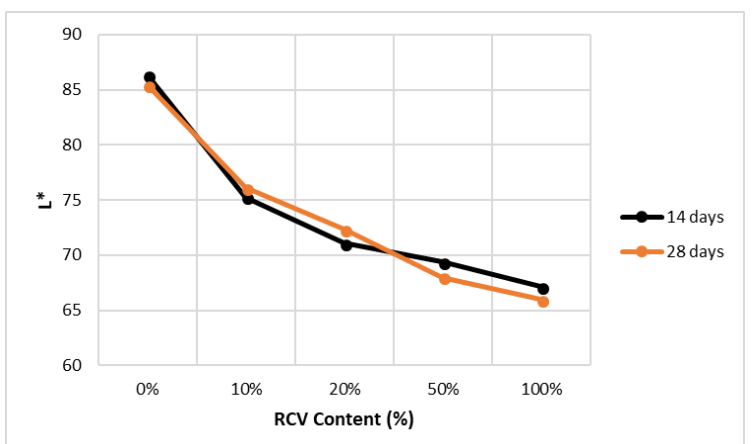

Figure 6. Effects of the content of RCR and of age of luminosity of $\mathrm{L}^{*}$ of samples with cure in laboratory $\left(23 \pm 2{ }^{\circ} \mathrm{C}\right)$. 
It is realizable that the variable of time of cure does not importantly interfere at the luminosity of samples cured in controlled temperature $\left(23 \pm 2{ }^{\circ} \mathrm{C}\right)$, identical situation as samples exposed to inclement weather according to Figure 7 .

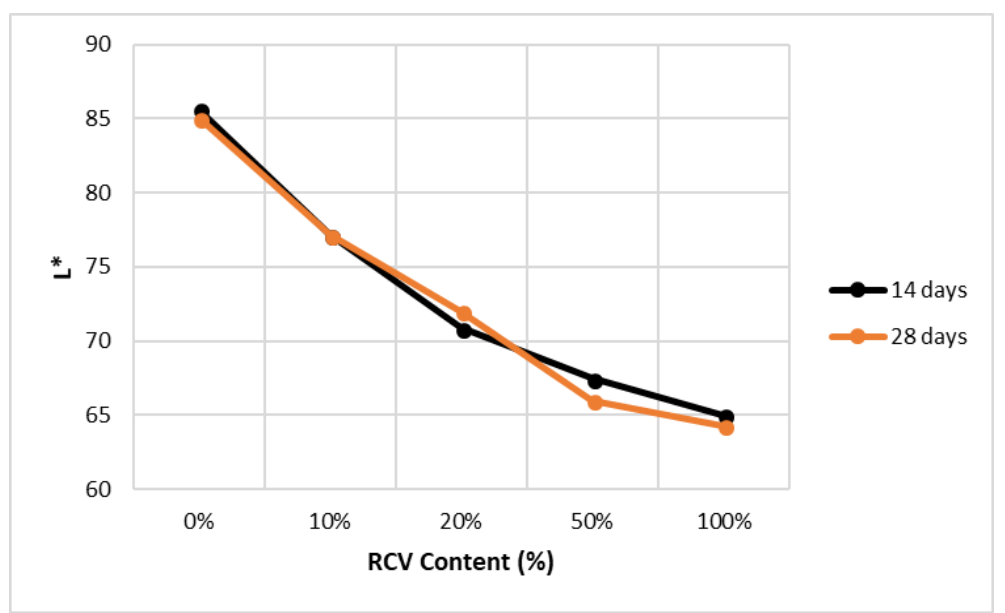

Figure 7. Effects of the content of RCR and of age of luminosity of $\mathrm{L}^{*}$ of samples with cure in an environment exposed to atmospheric conditions.

However, when the content of incorporated residue in reason to luminosity is analyzed, a decrease in the results of this property due to the increase of residue used is realized (Figure 8).

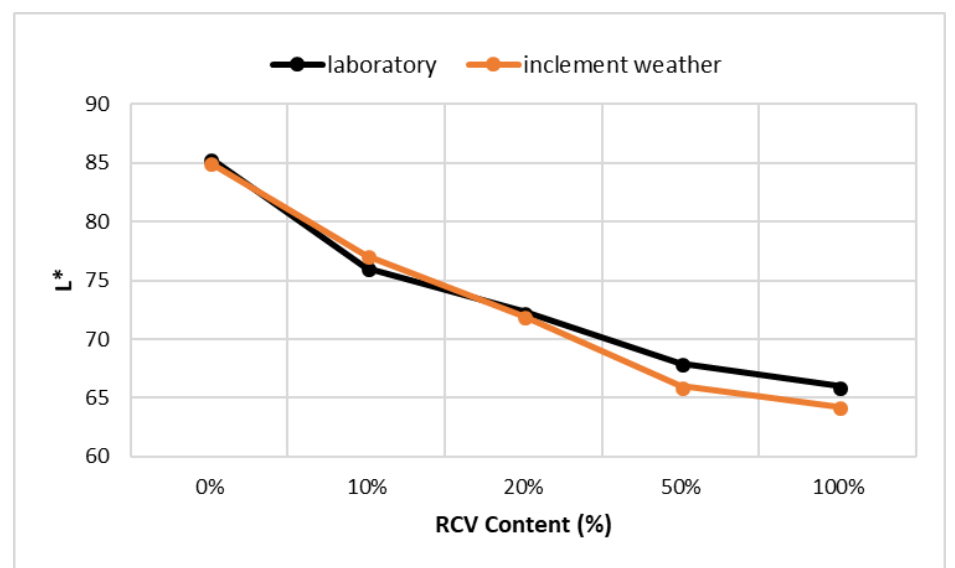

Figure 8. Effects of the content of waste and cured environments in luminosity $L^{*}$ of samples.

Starting from analysis of Figures 6,7 and 8 , it is noticeable that as there was an increase in the substitution of natural sand to RCR, the darker the surface of grout samples gets, independent of condition and time of cure. The residue, for showing bigger power of coloring, probably justified by the low dimension of its particles, resulted in darker toned samples.

Matias et al. [2], confirmed this result in their study, which verified that the RCR presented filer effect on cement mixtures, due to its fine particles. With the use of $100 \%$ of residue for example, the samples presented a tone in order of $22 \%$ and $2 \%$ darker, respectively, to controllable cure $\left(23 \pm 2{ }^{\circ} \mathrm{C}\right)$ and not controllable cure at age of 28 days, when compared to reference sample (M0). In the comparison of samples in different environments of cure, it is noticeable the same tendency presented in the figures, where the luminosity suffers significant effects only in variation of content of waste. 
The variance analysis (ANOVA) for the parameter $\mathrm{L}^{*}$ is presented on Tables 4 and 5 , as well as the significance of variables of study and its interactions.

Table 4. ANOVA of the independent factors and of the interaction between them in relation to the evolution of luminosity $\mathrm{L}^{*}$ with red ceramic residue in environment exposed to atmosphere conditions.

\begin{tabular}{cccccccc}
\hline Variation source & SS & DF & AS & Testing F & value $-\mathbf{p}$ & Critical F & Significant Effect \\
\hline Environment of cure (EC) & 0,876 & 1 & 0,876 & 0,654 & 0,464 & 7,709 & No \\
\hline EC*Residue percentage & 500,29 & 4 & 125,07 & 93,374 & 0,000 & 6,388 & Yes \\
\hline
\end{tabular}

SS- Sum of the squares, DF- Degree of freedom, AS- Average square, Testing F- Statistics F, Value P- Proof Value, Critical F - acceptance zone

Table 5. ANOVA of the independent factors and interactions between them in relation to the luminosity L* evolution with red ceramic residue in laboratory environment.

\begin{tabular}{ccccccccc}
\hline Variation source & SS & DF & AS & Testing F & Value $-\mathbf{p}$ & Critical F & Significant Effect \\
\hline Environment of cure (EC) & 1,176 & 1 & 1,176 & 1,584 & 0,277 & 7,709 & No \\
\hline & & & & & & & \\
\hline EC* Residue percentage & 522,05 & 4 & 130,51 & 175,765 & 0,000 & 6,388 & Yes \\
\hline
\end{tabular}

SS- Sum of the squares, DF- Degree of freedom, AS- Average square, Testing F- Statistics F, Value P- Proof Value, Critical F - acceptance zone

As expected, the increase in the content of residue influences significantly on final colorimetric features, presenting a big decrease on luminosity as the increase of RCR happens, demonstrating the waste's potential as pigment, justified fact by the iron oxide contained in ceramic materials [17]. In relation to the influence of the cure environment, this did not present significant effect on luminosity, as much on the comparison to exposition to atmospheric conditions as in laboratory environment.

\subsubsection{Parameter $\Delta \mathbf{E}$}

The global chromatic modification $\Delta \mathrm{E}$ represents the color variation of a material in relation to a reference pattern. In this work, the reference pattern consisted of two parameters $L^{*} a d^{*} b^{*}$ obtained in the testing at 14 days and its end at 28 days, in different conditions of exposure and used content, during different cycles which they were submitted to. This comparison allows establishing the increments or decreases on parameters and its chromatic implications. All results are mandatorily positive once they result from the hypotenuse formed by coordinates $\Delta \mathrm{L}^{*}, \Delta \mathrm{a}^{*}, \Delta \mathrm{b}^{*}$.

The graphics presented on sequence (Figures 9 and 10) show the values of parameter $\Delta \mathrm{E}$ in relation to the red ceramic residue content effect and cure time.

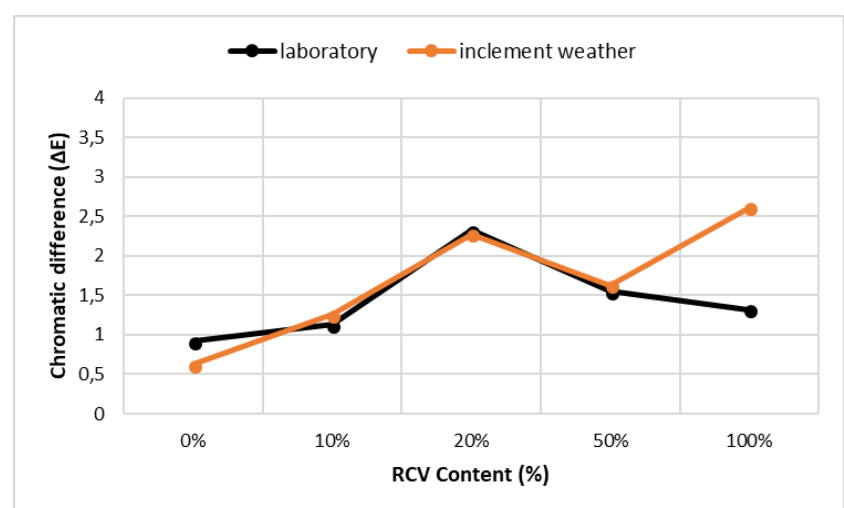

Figure 9. Effect of the content of residue and colorimetric difference $\Delta \mathrm{E}$ in different environment and same ages. 


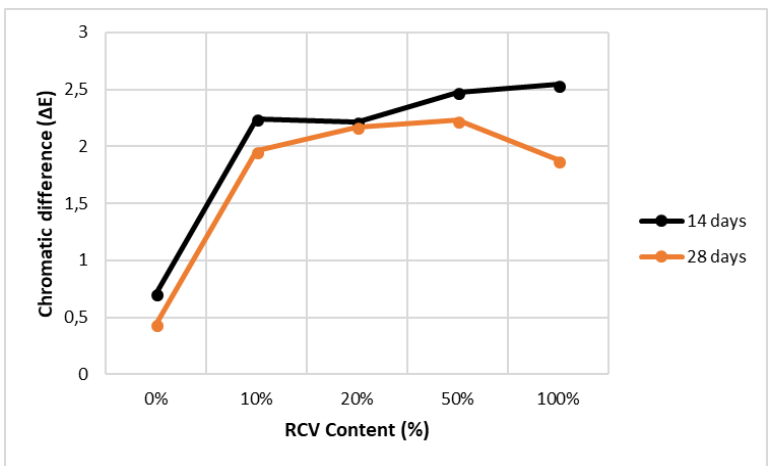

Figure 10. Effect of the content of waste and hydration ages to colorimetric difference $\Delta \mathrm{E}$ between 14 and 28 days.

Once the red ceramic residue was incorporated in the cement matrix, an increase in the colorimetric difference is noticed, besides that the comparison in different ages proves what was showed on Table 6, which exposed to environment with inclement weather, the samples present a bigger colorimetric difference (Figure 10).

Table 6. ANOVA of the independent factors and interactions between them in relation to colorimetric variation $\Delta \mathrm{E}$ to atmospheric conditions exposed environment.

\begin{tabular}{ccccccccc}
\hline Variation source & SS & DF & AS & Testing F & Value $-\mathbf{p}$ & Critical F & Significant Effect \\
\hline Hydration time (HT) & 0,229 & 1 & 0,229 & 9,185 & 0,039 & 7,708 & Yes & \\
\hline & & & & & & & & \\
\hline HT*Residue percentage & 4,370 & 4 & 1,092 & 43,722 & 0,001 & 6,388 & Yes & \\
\hline
\end{tabular}

SS- Sum of the squares, DF- Degree of freedom, AS- Average square, Testing F- Statistics F, Value P- Proof Value, Critical F - acceptance zone

In relation to the coloring differences to samples with different hydration time, but same exposure environment, it is noticeable that the results were very close to both environments, however Horgnies et al. [12] reports that the hydration rates must also influence in the final grout aesthetics, besides other factors as relation water/cement, additions and mixture composition, that in case of this present research, the last one caused bigger impact.

The analysis of variance (ANOVA) to the parameter $\triangle \mathrm{E}$ is presented on Tables 6 and 7.

Table 7. ANOVA of the independent factors and interactions between them in relation to colorimetric $\Delta \mathrm{E}$ variation to laboratory environment.

\begin{tabular}{cccccccc}
\hline Variation source & SS & DF & AS & Testing F & Value - p & Critical F & Significant Effect \\
\hline Hydration time (HT) & 0,133 & 1 & 0,133 & 0,701 & 0,449 & 7,708 & No \\
\hline & & & & & & & \\
\hline HT*Residue percentage & 2,947 & 4 & 0,737 & 3,887 & 0,108 & 6,388 & No \\
\hline
\end{tabular}

SS- Sum of the squares, DF- Degree of freedom, AS- Average square, Testing F- Statistics F, Value P- Proof Value, Critical F - acceptance zone

After the analysis of the variance performed, it was verified that some of the control factors and some interactions of first and second order presented significant effect. Besides that, the analysis shows that in the comparison of samples exposed to laboratory environment, the hydration time factor did not have significant influence in the coloring change. Opposite situation is observed on samples exposed to natural environment, showing that the exposure to inclement weather can damage the samples colorimetric intensity.

\subsection{Tensile Strength}

Figure 11 presents the average results of tensile in Tensile Strength performed at 28 days. 


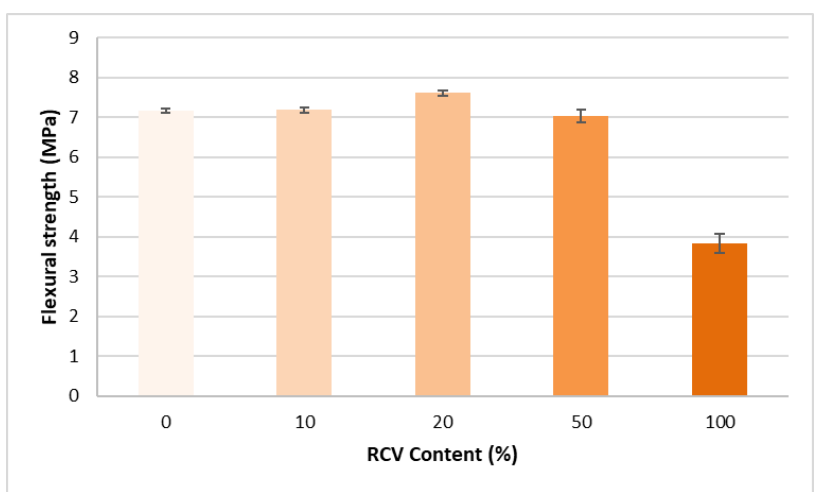

Figure 11. Average results of Resistance to Tensile Strength.

By analyzing Figure 11, it is noticeable that tendency to decrease in the Tensile Strength occurred, while the RCR was incorporated, emphasizing that the trace that showed bigger performance was the $20 \%$ one, validating the testing of compressive strength, similar result to Sales and Alferes [10], that by incorporating ceramic powder in concretes verified that the chemical and microstructural properties of residue decreased the Tensile Strength of the cement matrix. However, to evaluate if there was significant decrease among the analyzed traces, a variance analysis (ANOVA) was performed (Table 8).

Table 8. ANOVA of the influence of the content of residues in the Tensile Strength.

\begin{tabular}{cccccccc}
\hline Variation source & SS & DF & AS & Testing F & Value $-\mathbf{p}$ & Critical F & Significant Effect \\
\hline Up to 50\% RCR content & 0,564 & 3 & 0,188 & 0,419 & 0,744 & 4,066 & No \\
\hline & & & & & & & \\
\hline All RCR levels & 28,580 & 4 & 7,145 & 16,272 & 0,000 & 3,478 & Yes \\
\hline
\end{tabular}

SS- Sum of the squares, DF- Degree of freedom, AS- Average square, Testing F- Statistics F, Value P- Proof Value, Critical F - acceptance zone

After the analysis ANOVA, it is noticeable that the testing of Tensile Strength demonstrated a significant decrease only to the content of $100 \%$ of incorporation, to the other content the samples presented stable resistance when compared the reference sample. Li et al. [5], at using Galvanized Sludge as pigment in grouts, the same stability of traction strength was found, justifying the fact by the fill of the empties in the process of hydration of the paste, as the waste presents smaller granulometry and it has filer effect. However, the authors cited did not replace the small aggregate as in the present research, that in the content with $100 \%$ did not use small aggregate in the mixture, only RCR, which generated difficulty of particle bearing, so, many may have been in the perpendicular sense of force applied in the testing of resistance to Tensile Strength, whereas the ceramic waste presents more lamellar grains than the sand ones and generated fragile areas of rupture, justifying the decrease of resistance in this trace.

At evaluating the performance of the mixtures with the ABNT NBR 13281 [18], according to Table 9, it is possible to verify that all grouts were classified as R6, being superior to 3,5 MPa, fact the makes the use of RCR to the increase of mechanical resistance attractive, besides the pigment in grouts.

Table 9. Classification NBR 13281 [18] Tensile Strength.

\begin{tabular}{ccc}
\hline Class & Tensile Strength MPa & Method of testing \\
\hline R1 & $\leq 1,5$ & \\
R2 & 1,0 to 2,0 & ABNT NBR 13279 \\
R3 & 1,5 to 2,7 & \\
\hline R4 & 2,0 to 3,5 & \\
\hline R6 & 2,7 to 4,5 & $>3,5$ \\
\hline
\end{tabular}




\subsection{Compressive Strength}

The results obtained in the testing of resistance to compressive strength were performed at 28 days and are presented in the Figure 12 below.

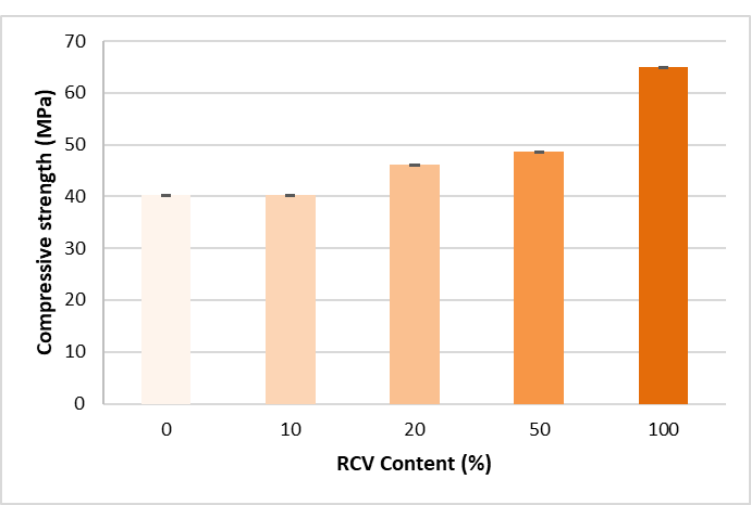

Figure 12. Average results of compressive strength.

It was verified that the content of replacement of sand by the RCR influenced in a significant way in the compression strength, as the variance (ANOVA) analysis shows (Table 10). This is related to the filer effect, with the fill of empties in the cement matrix, and probably to the pozzolan effect of the RCR, which was already verified by Amorim et al. [19], Jacoby and Pelisser [1] and Jang et al. [3], by using pozzolan materials, it occurs addition of compression strength of grouts. Jacoby and Pelisser [1] and Matias et al. [2], affirm that the pozzolan effect along with the fine particles, that is, the filer, reduce the porosity and guarantee bigger compactness of the cement matrix, consequently justifying the increase of compressive strength of the same.

Table 10. ANOVA of the influence of content of residue in compressive strength.

\begin{tabular}{cccccccc}
\hline Variation source & SS & DF & AS & Testing F & Value $-\mathbf{p}$ & Critical F & Significant Effect \\
\hline Residue percentage & $2.459,947$ & 4 & 614,987 & 70,294 & 0,00 & 2,759 & Yes \\
\hline
\end{tabular}

SS- Sum of the squares, DF- Degree of freedom, AS- Average square, Testing F- Statistics F, Value P- Proof Value, Critical F - acceptance zone

The increment of compressive strength of cement matrices at incorporating itself pozzolan waste as pigments, besides the adequate destination to a reject like the RCR, are attractive features in civil construction, since as according to Corinaldesi et al. [11] the commercial pigments reduce the compressive strength of concretes and grouts besides not being a sustainable alternative. By comparing the compression strength with the classifications of ABNT NBR 13281 [18], it is noticeable on Table 11 that all grouts are classified as P6, which is $>8 \mathrm{MPa}$, thus reaffirming the viability in the use of RCR, since it contributes on mechanical properties of composite.

Table 11. Classification of grouts in relation to compressive strength.

\begin{tabular}{ccc}
\hline Class & Compressive strength MPa & Method of testing \\
\hline P1 & $\leq 2,0$ & \\
P2 & 1,5 to 3,0 & ABNT NBR 13279 \\
\hline P3 & 2,5 to 4,5 & \\
\hline P4 & 4,0 to 6,5 & \\
\hline P6 & 5,5 to 9,0 & $>8,0$ \\
\hline
\end{tabular}




\subsection{Relation Between the Compressive and to Tensile Strength}

By analyzing Table 12 and the results cited above, it is noticeable that the residue of RCR influences more significantly in the compressive strength, whereas in the Tensile Strength, it is noticed a tendency of constancy of the results with different content of incorporation of residue. Authors as Amorim et al. [19], Jacoby and Pelisser [1] and Jang et al. [3] report that because the ceramic residue has pozzolan effect and microparticles, it tends to react in the mixture so by their chemical properties and generate better packing of the grains with the filer effect, thus generating an addition in the resistance of the grout. Yet Li et al. [5], found the same stability of Tensile Strength in their studies by incorporating galvanized sludge in the grouts. The common sense of the performed researches in materials similar to RCR is that the residue generates better fill of the empties in the mixture and it provides a pozzolan reaction, avoiding the significant decrease of the resistances of the grouts, even if the small aggregate is removed from the compositions of it. Thus, seen that the traces frame themselves inside the limits of the Brazilian standards, the RCR presents potential of application in grouts [19].

Table 12. Compression and to Tensile Strength.

\begin{tabular}{ccccc}
\hline Content (\%) & $\begin{array}{c}\text { Compression strength } \\
\text { (MPa) }\end{array}$ & Average detour Rc & $\begin{array}{c}\text { Tensile Strength } \\
\text { (MPa) }\end{array}$ & Average detour (Rt) \\
\hline 0 & 40,31 & 1,32 & 7,17 & 0,22 \\
\hline 10 & 40,23 & 1,05 & 7,19 & 0,35 \\
\hline 20 & 46,19 & 0,92 & 7,62 & 0,33 \\
\hline 50 & 48,57 & 4,29 & 7,03 & 0,79 \\
\hline 100 & 64,94 & 2,05 & 3,84 & 0,64 \\
\hline
\end{tabular}

\section{CONCLUSIONS}

Based on the results obtained with this study, it was possible to verify the following findings:

- By analyzing the L parameter, which is, the luminosity, it is noticeable that the increase of the content of replacement of sand by RCR influenced in a significant way on the colorimetric properties of the grouts, presenting lower luminosity, in other words, a bigger coloring, while the RCR was incorporated, having the distinct cure environment not influenced significantly on this property. The content of $100 \%$ was the one that presented lower luminosity and consequently better coloring.

- The different environments used in the cure process, caused colorimetric variations in the grouts by analyzing the parameter $\Delta \mathrm{E}$, whereas the samples exposed to inclement weather presented bigger differences of pigment in the time gaps analyzed.

- Concomitantly to the increase of the content of RCR in the grouts there has been an addition of compression strength.

- The trace with the content of $20 \%$ presented the best performance of Tensile Strength, whereas in the others, a decrease occurred in this property when adding RCR.

- Relating the compressive strength and the tensile strength to the color of the samples, it was found that the trace that guaranteed the appropriate mechanical properties and satisfactory coloring in relation to the reference was the $50 \%$ incorporation of red ceramic, since the trace with $100 \%$ of incorporation obtained the most pigmented color, but presented a brittle surface. However, even with the drop in tensile strength in the line with $100 \%$ RCR incorporation, all mortars obtained classification according to NBR 13281 of P6 and R6 for compressive strength and tensile strength, respectively, being thus indicated for use and reaffirming the feasibility of incorporating RCR into the mixtures.

- Therefore, the viability of RCR use to replace the small aggregate in grouts being demonstrated, studies, in order to analyze the real influence of this residue in a long-term within the composite, are required.

\section{REFERENCES}

[1] P. C. Jacoby and F. Pelisser, "Pozzolanic effect of porcelain polishing residue in Portland cement," J. Clean. Prod., vol. 100, pp. 8488, Aug 2015.

[2] G. Matias, P. Faria, and I. Torres, "Lime mortars with ceramic wastes: characterization of components and their influence on the mechanical behaviour," Constr. Build. Mater., vol. 73, pp. 523-534, Dec 2014. 
[3] H. Jang, H. Kang, and S. So, "Color expression characteristics and physical properties of colored mortar using ground granulated blast furnace slag and white Portland cement," KSCE J. Civ. Eng., vol. 18, no. 4, pp. 1125-1132, Apr 2014.

[4] M. C. Zurita Ares, E. Villa González, A. I. Torres Gómez, and J. M. Fernández, "An easy method to estimate the concentration of mineral pigments in colored mortars," Dyes Pigments, vol. 101, pp. 329-337, Feb 2014.

[5] H. Li, X. Yang, Z. Suo, Y. Xia, and D. He, "Red cement-based decorative mortar prepared with dry electroplating sludge containing $\mathrm{Pb}$ as red pigment," Journal of Wuhan University of Technology-Mater. Sci. Ed., vol. 29, pp. 291-297, Apr 2014.

[6] M. V. Diamanti, B. Del Curto, M. Ormellese, and M. P. Pedeferri, "Photocatalytic and self-cleaning activity of colored mortars containing $\mathrm{TiO}_{2}, "$ Constr. Build. Mater., vol. 46, pp. 167-174, Sep 2013.

[7] G. Lemaire, G. Escadeillas, and E. Ringot, "Evaluating concrete surfaces using an image analysis process," Constr. Build. Mater., vol. 19, no. 8, pp. 604-611, Oct 2005.

[8] A. López, J. M. Tobes, G. Giaccio, and R. Zerbino, "Advantages of mortar-based design for coloured self-compacting concrete," Cement Concr. Compos., vol. 31, no. 10, pp. 754-761, Nov 2009.

[9] H. Lee, J. Lee, and M. Yu, "Influence of iron oxide pigments on the properties of concrete interlocking blocks," Cement Concr. Res., vol. 33, no. 11, pp. 1889-1896, Nov 2003, http://dx.doi.org/10.1016/S0008-8846(03)00209-6.

[10] A. T. C. Sales and R. S. Alferes Fo., "Efeito do pó de resíduo cerâmico como adição ativa para concreto," Ambient. Constr., vol. 14, no. 1, pp. 113-125, Jan/Mar 2014.

[11] V. Corinaldesi, S. Monosi, and M. L. Ruello, "Influence of inorganic pigments' addition on the performance of coloured SCC," Constr. Build. Mater., vol. 30, pp. 289-293, 2012.

[12] M. Horgnies, E. Darque-Ceretti, E. Gueit, and M. Aucouturier, "Characterisation of the variations of tint and the adhesion of pigments onto the surface of mortar," Constr. Build. Mater., vol. 94, pp. 380-386, Sep 2015.

[13] Associação Brasileira de Normas Técnicas, Argamassa para Assentamento e Revestimento de Paredes e Tetos - Preparo da Mistura e Determinação do Índice de Consistência, NBR 13276: 2016, 2005.

[14] Instituto Nacional de Metereologia. “Estações e dados.” INMET. http://www.inmet.gov.br (accessed May 22, 2018).

[15] D. Vázquez-Nion, P. Sanmartin, B. Silva, and B. Prieto, "Reliability of color measurements for monitoring pigment content in a biofilm-forming cyanobacterium," Int. Biodeterior. Biodegradation, vol. 84, pp. 220-226, Oct 2013.

[16] Associação Brasileira de Normas Técnicas, Argamassa para Assentamento e Revestimento de Paredes e Tetos - Determinação da Resistência à Tração na Flexão e à Compressão, NBR 13279: 2005, 2005.

[17] S. R. Prim, M. V. Folgueras, M. A. de Lima, and D. Hotza, "Synthesis and characterization of hematite pigment obtained from a steel waste industry," J. Hazard. Mater., vol. 192, no. 3, pp. 1307-1313, Sep 2011.

[18] Associação Brasileira de Normas Técnicas, Argamassa para Assentamento e Revestimento de Paredes e Tetos - Requisitos, NBR 13281: 2005, 2005.

[19] L. V. Amorim, H. L. Lira, and H. C. Ferreira, "Use of residential construction waste and residues from red ceramic industry in alternative mortars," J. Environ. Eng., vol. 129, no. 10, pp. 916-920, Oct 2003.

Author contributions: LAD: funding acquisition, methodology, conceptualization, writing, analysis; FBB and LK: methodology, conceptualization, analysis; DCMA and ASV: conceptualization, writing, supervision.

Editors: Bernardo Tutikian, Guilherme Aris Parsekian. 